\title{
PSICANÁLISE E NEUROCIÊNCIA: UM MAPA DOS
}

DEBATES

\author{
Márcia Moraes Davidovich
}

$\mathrm{Na}$ presente dissertação elaboramos um mapa dos debates sobre a possibilidade de se articular psicanálise e neurociência, em que identificamos três grupos principais, cada um com seus próprios pressupostos, em função dos quais lhes atribuímos diferentes designaçōes: hibridação, isolamento e interlocução. $\mathrm{Na}$ medida em que os debates sobre psicanálise e neurociência tendem a abarcar a questão da (a)cientificidade da psicanálise, decidimos, a fim de oferecer consistência ao nosso trabalho, investigar esta questão.

\section{BANCA:}

Monah Winograd (Orientadora)

Benilton Carlos Bezerra Junior

Flavia Sollero de Campos

Data da defesa: 28/01/2009 